\title{
O ironii jako figurze retorycznej i postawie moralnej (z odniesieniem do Wittlina i Kierkegaarda)
}

\begin{abstract}
Szewczyk-Haake Katarzyna, O ironii jako figurze retorycznej i postawie moralnej (z odniesieniem do Wittlina i Kierkegaarda) [Irony as a figure of speech and moral stance (with regard to Wittlin and Kierkegaard)]. „Przestrzenie Teorii” 24, Poznań 2015, Adam Mickiewicz University Press, pp. 13-29. ISBN 978-83-232-2982-7. ISSN 1644-6763. DOI 10.14746/ pt.2015.24.1.

In his work as a writer, Józef Wittlin searched for literature able to grant the reader moral support, while at the same time being artistically successful. In his novel Salt of the Earth, the way to combine these two, to a certain extent contradictionary aims, is found in the use of irony. An analysis of the classical types of irony appearing in the novel (naive irony, irony of the sender, verbal irony) leads to the conclusion that each of those was remarkably modified by the author. As a result, the "ironical anthropology" created by Wittlin in his novel lacks any elements of simple moralizing or giving ready-made moral solutions, but brings a striking image of a human community, unified not by a common status, but by a common fate. In the novel, irony turns out to be not only a textual figure, but first and foremost a moral stance, approximate to that of Socrates as described by Kierkegaard. Thanks to this stance, Wittlin enthuses his readers with the longing for the ideal, shaping their moral sensibility, at the same time granting them the sovereignty to which the reader of a literary work should be entitled.
\end{abstract}

Na kilka lat przed wydaniem Soli ziemi deklarował Józef Wittlin w przedmowie do nieukończonej książki Święty Franciszek $z$ Asyżu, że nie interesuje go literatura, której sens sprowadza się do uświadomienia ludzkości jej własnej, marnej kondycji, lecz taka, która zdolna jest w odbiorcy wywołać refleksję moralną i natchnąć choćby umiarkowanym optymizmem co do ludzkich możliwości etycznego postępowania1. Był jednak Wittlin jednocześnie pisarzem, który niechętnie spoglądał na dzieła (i ludzi) w nazbyt pewny sposób głoszące jednoznacznie brzmiące racje, czy to natury ideologicznej, czy religijnej, wyraźnie nachylające się ku dydaktyce i moralistyce, pozbawione kompozycyjnego i intelektualnego niuansowania ${ }^{2}$. Nietrudno zauważyć, że potrzeby te mogą uchodzić za sprzeczne, związane są bowiem z radykalnie odmiennymi postawami życiowymi (moralizm i antyfundamentalizm) i biegunowo różnymi kon-

1 J. Wittlin, Pisma pośmiertne i inne eseje, Warszawa 1991, s. 56 i nast. (Pierwodruk: 1931. Tekst datowany: Assyż w maju 1926).

2 Por. np. uwagi Wittlina w ogłoszonych w Orfeuszu w piekle XX wieku esejach „Jésus” Barbusse'a (pierwodruk 1927) i „Święty Franciszek” Chestertona (pierwodruk 1927). 
cepcjami dzieła literackiego ( $\mathrm{w}$ prozie dwudziestolecia międzywojennego reprezentowanymi przez powieść perswazyjną z jednej, a poetycki model prozy z drugiej strony3).

W niniejszym artykule podejmuję lekturę Soli ziemi zorientowaną na wydobycie z powieści tego jej szczególnego wymiaru, jakim jest godzenie przez jej autora głębokiego przywiązania do wartości z wyraźną idiosynkrazją wobec gotowych ideologii i łatwych prawd. Kluczem interpretacyjnym, który, jak sądzę, pozwala zrozumieć, w jaki sposób i w jakim stopniu Wittlinowi udała się sztuka pogodzenia tych sprzeczności, jest ironia, rozumiana zarówno jako obecna $\mathrm{w}$ tekście powieści wszechogarniająca figura, jak i jako postawa podmiotu mówiącego, pytanie zaś, które nieustannie będzie mi towarzyszyć, brzmi: w jakich okolicznościach, mimo wątpliwości natury moralnej, jakie użycie ironii w sposób nieunikniony wzbudza, ironista może być - moralistą?

\section{Mit - ironia - moralność}

Ważną kategorią interpretacyjną przywoływaną wielokrotnie (i nierzadko z przekonującym rezultatem) w odniesieniu do powieści Wittlina jest mit4, który w kontekście pytań o „literaturę moralną” wydaje się dość wygodnym kluczem o tyle, o ile mityzacja świata zawsze kieruje ku konkretnym koncepcjom etycznym i zasadom moralnym. Wydaje się wszelako, że interpretacje te pozostają niepełne o tyle, o ile zbywają milczeniem lub traktują marginalnie problem ironii, czyli kwestię, która dla rekonstrukcji znaczeń powieści jest kluczowa ${ }^{5}$. Zastosowanie tego chwytu teks-

3 Por. K. Jakowska, Międzywojenna powieść perswazyjna, Warszawa 1992; W. Bolecki, Poetycki model prozy międzywojennej, Wrocław 1983. O napięciu między tymi biegunami pisze Jakowska (dz. cyt., s. 26), wskazując na dzieła mediujące skutecznie między skrajnościami (jej zdaniem udało się to Witoldowi Gombrowiczowi w Ferdydurke i Witkacemu); w poczet tych dzieł należałoby zapewne, w świetle dalszych rozważań, zaliczyć także Sól ziemi.

${ }^{4}$ Zob. np. K. Jakowska, Z dziejów ekspresjonizmu w Polsce. Wokót „Soli ziemi”, Wrocław 1977; E. Wiegandt, Wstęp, [w:] J. Wittlin, Sól ziemi, Wrocław 1991, s. LXXIV; A. Biała, Wittlinowski mit o wiecznym pokoju, [w:] tejże, $W$ kręgu polskich mitów literackich XX wieku, Piotrków Trybunalski 2000, s. 26-60.

${ }_{5}$ Zwrócił na to uwagę i sformułował na temat Wittlinowskiej ironii szereg trafnych intuicji Bogusław Bakuła - zob. tegoż, „Sól ziemi” Wittlina w naukowym opracowaniu, „Teksty Drugie” $1994 \mathrm{nr}$ 5/6, s. 167-169. Nieco uwagi poświęciła zagadnieniu ironii w powieści Wittlina Zoya Yurieff (tejże, Józef Wittlin, przeł. M. Szczubiałka, Izabelin 1997). Formułując tezę, iż: „Sól ziemi nie tylko należy uważać za powieść w znacznej mierze ironistyczną, lecz można nawet zaliczyć ją do kanonu ironistycznej literatury" (tamże, s. 91), Yurieff zwraca uwagę na różne aspekty i funkcje ironii - zwłaszcza satyryczną oraz potęgującą tragikomiczny wyraz powieści, które z grubsza można by chyba uznać za po- 
towego znacznie utrudnia ulokowanie „racji moralnej” w konkretnym punkcie, ironista bowiem wyklucza i neguje, nie zaś afirmuje. Umniejszając jej znaczenie $\mathrm{w}$ powieści na rzecz jej struktury mitograficznej, nie doceniono faktu, że obecna w Soli ziemi ironia pośrednio wskazuje na ułomność mitotwórczych zabiegów ${ }^{6}$. Tymczasem w lekturze pisarstwa Wittlina nastawionej na weryfikację tezy o poszukiwaniu przezeń drogi wiodącej w stronę „literatury moralnej” problem ironii w Soli ziemi ma znaczenie zupełnie zasadnicze. Będąc pomocnym w dokonaniu ustaleń dotyczących zawartego w powieści światopoglądu (wokół którego zresztą narosło wiele badawczych kontrowersji, poświadczających rangę powieści jako arcydzieła podatnego na coraz to nowe odczytania), zagadnienie ironii pozwala również ukazać Wittlinowską strategię pisarską i wysiłek nakierowany na stworzenie takiej formy literackiej, która pozwoliłaby uciec od dydaktyzmu i głoszenia jednoznacznych formuł aksjologicznych, w zamian zmuszając czytelnika do ciągłego namysłu nad istotą moralnego ujmowania świata.

Funkcje ironii w Soli ziemi są zróżnicowane. Po pierwsze wskazać można na estetyczną funkcję ironicznego opisu rzeczywistości, pozwalającą w pewnej przynajmniej mierze zamaskować dydaktycznie nacechowane autorskie zamierzenie. Ta potrzeba usuwania z pola widzenia czytelnika wyznaczników formalnych dydaktyzmu ukrytego w utworze była rzeczą pożądaną $\mathrm{w}$ dziele literackim od przynajmniej kilku pokoleń pisarskich przed Wittlinem, a literatura dziewiętnastego stulecia wypracowała szereg chwytów służących przeniesieniu perswazji w rejony inne niż bezpośredni wykład zasad; pośród tych chwytów znalazła się także ironia ${ }^{7}$. O ile - jak u Wittlina - wykorzystuje się ją na sposób subtelny, zjednuje ona czytelników, bo traktuje ich jako świadomych uczestników procesu interpretacji.

Zwiększająca szanse na estetyczny sukces ironicznego ujęcia „niezauważalność tezy"8 wiąże się jednak z pewnym zasadniczym ryzykiem

krewne ironii nadawcy i ironii losu. Garść wstępnych ustaleń na temat ironii w Soli ziemi poczynił niedawno Wojciech S. Wocław (Świat - igrzysko ironisty. Rozważania o „Soli ziemi” Józefa Wittlina, [w:] Etapy Józefa Wittlina, red. W. Ligęza, W.S. Wocław, Kraków 2014, s. 89-97), nie próbując jednak analizy poszczególnych jej odmian ani diagnozy jej roli dla całościowej wymowy powieści. Trafne spostrzeżenia dotyczące Wittlinowskiej ironii, choć będące odpryskiem analizy koncentrującej się na innym zagadnieniu, znaleźć można natomiast w tekście Łukasza Tischnera „Sól ziemi”, czyli tęsknota do eposu, [w:] Etapy Józefa Wittlina..., s. 13-40.

${ }^{6} \mathrm{~W}$ tym kontekście warto przypomnieć uwagi Łukasza Tischnera, który wskazuje na Wittlinowską "tęsknotę do eposu”, dodajmy - tęsknotę niespełnioną. Zob. Ł. Tischner, dz. cyt., s. 39 .

${ }^{7}$ Por. K. Jakowska, Międzywojenna powieść perswazyjna..., s. 264 i nast.

8 Tamże, s. 99. 
dla pisarza o moralistycznych skłonnościach. Jak wiadomo, poziom literackiego skomplikowania tekstu operującego ironią stawia przed odbiorcą wysokie wymagania, zaś czytelnik, który nie zorientuje się w sytuacji (o co stosunkowo łatwo, bo wyznaczniki ironii sa zazwyczaj dobrze ukryte ${ }^{9}$ ), może zrozumieć tekst błędnie - $\mathrm{z}$ tym właśnie, jak pisze badaczka, związana jest „podstawowa dwuznaczność zjawiska ironicznego”10. Fakt, że artyzm ironisty wzbudza w świadomym ironii czytelniku niekłamany zachwyt, jest niewątpliwą zaletą tekstu z punktu widzenia estetycznego, dla pisarza-moralisty wszelako może stać się przyczyną katastrofy, nadawca ryzykuje bowiem, że jego przesłanie nie zostanie zrozumiane lub zostanie pojęte opacznie. Wynika to $\mathrm{z}$ wpisanego $\mathrm{w}$ udaną wypowiedź ironiczną momentu niepewności lektury, sprawiającego również, że wszelkie wypowiedzi ironiczne ujmować można tyleż jako zawierające w sobie pewne zdania czy sądy, ile jako zaledwie sugerujące pewne obrazy czy postawy ${ }^{11}$. Co zaś najistotniejsze, ironia rozumiana jako pewna postawa charakteryzująca wypowiedź lub sposób myślenia może budzić zastrzeżenia natury moralnej, albowiem w punkcie wyjścia wydaje się ona nieuchronnie zakładać pewien dystans, a więc perspektywę, która $\mathrm{z}$ moralnego punktu widzenia pozostaje dyskusyjna ${ }^{12}$.

W którym miejscu zatem upatrywać moralnej wartości wypowiedzi formułowanej przez wytrawnego ironistę - o ile nie chcemy z góry założyć, że Wittlin w swym literackim zamierzeniu pogodzenia wody $\mathrm{z}$ ogniem jest skazany na porażkę?

Jak sądzę, funkcję ironii w Soli ziemi jako ważnego elementu strukturalnego „literatury moralnej” można pojmować na dwa sposoby. Pierwszy związany jest z użyciem ironii jako figury 13 i możliwy do wytropienia na drodze analizy występujących w Soli ziemi klasycznych odmian ironii: prostaczka, narratora, sytuacyjnej, tragicznej. Drugi - z tym, jak postawa ironiczna, której prototypem jest Sokrates w interpretacji Kierkegaar$\mathrm{da}^{14}$, inicjuje postawę otwarcia się na wartości oraz umożliwia zaistnie-

${ }^{9}$ Por. C. Kerbrat-Orecchioni, Ironia jako trop, przeł. M. Dramińska-Joczowa, [w:] Ironia, red. M. Głowiński, Gdańsk 2002, s. 125-126.

10 Tamże.

${ }_{11}$ D. Sperber, D. Wilson, Ironia a rozróżnienie między użyciem a przywołaniem, przeł. M.B. Fedewicz, [w:] Ironia..., s. 77.

12 Por. D.S. Kaufer, Ironia, forma interpretacyjna $i$ teoria znaczenia, przeł. M.B. Fedewicz, [w:] Ironia..., s. 149.

13 Por. J. Ziomek, Retoryka opisowa, Wrocław 2000, s. 241-244.

14 Wittlin znał i poważał refleksję filozoficzną duńskiego myśliciela. Sugestię Kierkegaardowskiej proweniencji poetycko opracowanego przez Wittlina tematu trwogi zgłosiła w kontekście analizy Hymnów Irena Maciejewska (zob. tejże, Józef Wittlin, [w:] Poeci dwudziestolecia międzywojennego, t. 2, red. I. Maciejewska, Warszawa 1982, s. 507), wątki 
nie na gruncie dzieła literackiego odmiany metody majeutycznej, dzięki działaniu której czytelnikowi poddana zostaje intuicja, że znajdujące się w stanie uwiądu moralne wartości mogą zostać przez człowieka na nowo ożywione. Postawa ironiczna pełni więc funkcję dydaktyczną, w sposób wszelako zupełnie inny, niż tradycyjny wykład zasad, przez ironistę traktowany z oczywistym dystansem.

\section{Ironia prostaczka: modyfikacje}

Zanalizujmy na początek dwa reprezentatywne dla powieści fragmenty, w których ujawnia się osławiona Wittlinowska ironia prostaczka ${ }^{15}$, wyzyskująca chwyt mowy pozornie zależnej:

Nagle cesarz Franciszek spojrzał na Piotra Niewiadomskiego. Patrzył nań z krzyża, co był przypięty na biało-czerwonej wstążeczce do bluzy żandarma z okazji sześćdziesięciu lat wstąpienia na tron. Tam, gdzie przecinały się ramiona krzyża, złocił się biust cesarza, otoczony wieńcem. Bóg bowiem i cesarz zawsze trzymają się razem. Blaszane, zimne oczy Franciszka Józefa kłuły Piotra przez bluzę, przez zapocona koszulę i wdzierały się aż do sumienia. Kto w takiej godzinie dobrowolnie nie posłucha cesarza, który z krzyża woła, temu sam Jezus nie przebaczy na Ostatecznym Sądzie ${ }^{16}$. (s. 55-56)

Kierkegaardowskie w dziele autora Soli ziemi sygnalizowali także Krzysztof Kłosiński (tegoż, Cztery interpretacje ofiary Abrahama. Wokót wiersza Józefa Wittlina „Trwoga przed śmiercia”, [w:] Szkice o poezji Józefa Wittlina, red. I. Opacki, Katowice 1990, s. 56 i nast.), Romuald Cudak („Otom przed Toba, Abraham”. Lektura wiersza Józefa Wittlina „Trwoga przed śmiercia”, [w:] Szkice o poezji Józefa Wittlina, s. 50 i nast.) i Julian Rogoziński (tegoż, Wstęp, [w:] J. Wittlin, Poezje, Warszawa 1981, s. 17). Należy dodać, że w dziełach Wittlina (zarówno utworach ogłoszonych drukiem - Kapliczka nieczystego sumienia oraz Tragiczny Gogol [pierwodruk 1932] - jak i pozostających w rękopisach - esej Nekrofilosemityzm [rękopis w posiadaniu Muzeum Literatury w Warszawie, sygn. 945]) można odnaleźć odwołania do pism Duńczyka, a nawet dosłowne cytaty. Świadczą one (co w dotychczasowych badaniach nie zostało stwierdzone), że Wittlin znał Wybór pism Kierkegaarda w polskim tłumaczeniu M. Bienenstocka, które ukazało się w 1914 roku we Lwowie w serii 'Symposion'. Nadto, istniały (choć jedynie fragmentaryczne) przekłady wcześniejsze (por. bibliografia sporządzona przez A. Szweda w tomie Kierkegaard's International Reception, vol. 2, ed. by J. Stewart, Ashgate Publishing Ltd., 2009, s. 230-243), zaś Wittlin, znający doskonale język niemiecki, mógł czytać pisma Kierkegaarda także w tłumaczeniach niemieckich. W niniejszym artykule, z racji ograniczonego miejsca, sygnalizuję jedynie ten bardzo obszerny wątek, jakim jest Wittlinowska fascynacja myślą autora Bojaźni $i$ drżenia i ograniczam się do wskazania pewnych analogii w poglądach obu na istotę ironii.

${ }^{15}$ Por. B. Bakuła, „Sól ziemi” w naukowym opracowaniu..., s. 168.

${ }^{16}$ Wszystkie cytaty z powieści Wittlina podaję za wydaniem: J. Wittlin, Sól ziemi, Wrocław 1991. W nawiasie po cytacie wskazuję numer strony. 
Czy można sobie wyobrazić wojnę prowadzoną w surdutach, serdakach, chałatach, krawatach, w melonikach i jarmułkach? Nie, takiej wojny nawet Piotr Niewiadomski nie mógł sobie wyobrazić. Dobrze rozumiał, że tylko w mundurze wolno zabijać człowieka i tylko w banderoli, w państwowym opakowaniu ciał ważna jest śmierć za cesarza. [...] A jak Bóg stworzył człowieka na własny obraz i podobieństwo, tak i cesarz dawał człowiekowi mundur, żeby go choć trochę do siebie upodobnić. Naturalnie wielka była różnica miedzy mundurem samego cesarza a mundurem, który miał dzisiaj włożyć Piotr. No, ale też między obu tymi śmiertelnikami niemała była różnica. (s. 246)

Jak widać już na pierwszy rzut oka, głos narratora i wyrażane niekiedy za jego pośrednictwem spojrzenie na świat bohatera tworzą piętrową strukturę, w której czynnikiem nadrzędnym bywają na zmianę oba tworzące ją elementy: czasami sposób myślenia bohatera zostaje ujawniony tylko w pojedynczych zdaniach, czasem zaś bywa on pierwszoplanowy. Trudno w praktyce klarownie odróżnić sytuacje, kiedy to ironista-narrator po prostu przedstawia ironiczną sytuację (jej ironia polegałaby na tym, że Piotr wierzy głęboko w słuszność sakralizujących rytuałów, do których ucieka się armia, a także uważa cesarza za równego we wszystkim Chrystusowi) od sytuacji, w której między narratorem-ironistą a bohaterem-prostaczkiem zawiązuje się pewna wspólnota, gdyż narrator $\mathrm{w}$ istocie zgadza się $\mathrm{z}$ mimochodem dokonującą się $\mathrm{w}$ spojrzeniu Piotra ocena pewnych zjawisk i patologii.

Zachodzi tu ponadto jeszcze jedna komplikacja: w klasycznej ironii naiwnej bohater-prostaczek nie może zrozumieć pokrętnych wywodów, których jest świadkiem i z tego powodu staje się bezpośrednim rzecznikiem narratora-ironisty ${ }^{17}$. W Soli ziemi tymczasem naiwny bohater czyni wszystko, by właśnie pojacć i oswoić absurdalną sytuację, w której się znalazł. W tym sensie, jako człowiek głęboko pragnący zrozumieć i zinterioryzować mechanizmy działania armii (co pozwoliłoby mu poczuć się w jej realiach jak u siebie), bohater nie staje się oczywiście głosem narratora, przeciwnie, w swej nieustannie wyrażanej wierze w cesarza jest biegunowo odległy od tego, co na temat mechanizmów władzy sądzi narrator. Niewątpliwie jednak naiwność Piotra, będąca źródłem ironicznych sytuacji, w jakich ów się znajduje, pozwala narratorowi-ironiście obnażyć istotę absurdalności wojska; koniec końców więc to, co można by uznać za krytykę umysłowego ograniczenia i poziomu religijnej samoświadomości Piotra, okazuje się ostatecznie atakiem na duchową i moralną pustkę nowoczesności (która sprawia, że prosty człowiek łatwo zapełnia próżnię po Absolucie bóstwami innego rodzaju) oraz wykorzystywane przez armię

17 Por. D.S. Muecke, Ironia: podstawowe klasyfikacje, przeł. G. Cendrowska, [w:] Ironia..., s. 74 . 
mechanizmy socjotechniczne. Oczywista dla obserwatora zewnętrznego odmienność między religijnym systemem chrześcijaństwa a porządkiem wojskowej struktury stawia Piotra w sytuacji ironicznej (nie pojmuje on ewidentnej różnicy między nimi), ale też ironicznie wskazuje na uzurpację, jakiej dopuszcza się państwo, przejmując rytuał i stwarzając pozór własnego wszechmocnego i pozaziemskiego statusu.

Dwukierunkowość ironii prostaczka pozostaje cechą charakterystyczną Soli ziemi. Zarazem warto zauważyć, że ironiczna sytuacja, w jakiej postawiony jest Piotr, każdorazowo zawiera w sobie, prócz komizmu, wyraźny odcień tragiczny, gdyż wynika z niewiedzy, która gorliwie poszukuje wyjaśnienia dla wszechogarniających wątpliwości rodzących lęk przed światem ${ }^{18}$ i prowadzi do powstania nieadekwatnego obrazu rzeczywistości, który zawsze pozostaje czymś niosącym utajone i uśpione niebezpieczeństwo. Wittlin wydaje się rozumieć doskonale powstały w nowoczesności mechanizm rozpaczliwego niekiedy rekonstruowania horyzontu sensu oraz poszukiwania gwarancji światopoglądowej pewności i (w przeciwieństwie do wielu piewców moderny) wyraźnie widzi związane z nim zagrożenia: w perspektywie jednostki działania takie wiodą do łatwego ulegania ideologiom, w perspektywie zaś życia zbiorowości prowadzą prostą drogą do zagrożeń totalitarnych ${ }^{19}$.

Nieprzypadkowo w licznych fragmentach, w których dochodzi do głosu ironia prostaczka, istotne miejsce zajmuje analogia. Poszukiwanie porządku w otaczającej go, niepojętej rzeczywistości wojskowej prowadzi Piotra do ustanawiania paraleli między porządkiem religijnym i tym panującym w armii. Nieścisłości, jakie mogą pojawić się na tej drodze (wątpliwość, czy mundur rekruta wystarczająco przypomina mundur cesarza), łatwo da się zażegnać, opierając się znów na głębokiej strukturze odpowiedniości (różnica między ludźmi znajduje odzwierciedlenie w różnicy stroju). Analogia jest rodzajem wnioskowania wykorzystywanym w argumentacji ${ }^{20}$, toteż wywody Piotra za sprawą ustanowienia różnorakich podobieństw zyskują (w jego oczach przynajmniej) siłę dowodu. Oczywista z perspektywy narratora i czytelnika kuriozalność Piotrowych

18 Wittlin często powracał do sytuacji niepewności poznawczej i egzystencjalnej człowieka oraz rodzącego się w niej lęku. Doznania te opisał m.in. w Trwodze przed śmiercia ważnym wierszu z debiutanckich Hymnów, w którym tytułowa trwoga ma swe istotne źródło właśnie w wątpliwościach co do losu człowieka po śmierci w sytuacji, gdy istnienie Boga nie jest czymś oczywistym, a jej egzorcyzmowanie odbywa się na drodze dążenia do pewności („O Panie! [...] spraw, żebyś był, - / bo ja nie chcę umrzeć!” - Trwoga przed śmiercia, [w:] J. Wittlin, Hymny, Poznań 1920, s. 15-16).

19 Por. P. Juszkiewicz, Cień modernizmu, Poznań 2013.

${ }^{20}$ M. Korolko, Sztuka retoryki, Warszawa 1990, s. 89. 
enuncjacji (zauważmy, że bohater, sam siebie utwierdzając za pomocą fałszywych analogii w błędnych mniemaniach, ponownie staje w pozycji potencjalnej ofiary własnego błędu) lokuje Piotra w sytuacji ironicznej. Źródła ironii można upatrywać z jednej strony w uroszczeniach Piotra do ogarniania własnym, wątłym intelektem spraw, które go przerastają i wówczas jej ofiarą paść musi sam bohater; z drugiej sytuacja ironiczna wydaje się wynikać z faktu, że człowiek - zwłaszcza zaś człowiek nowoczesny, odarty z wszelkiej pewności metafizycznej - szuka gorliwie „znaków odpowiedniości” w otaczającym go świecie, choć brak mu najczęściej po temu stosownych podstaw. Te wciąż ponawiane przez Piotra próby tworzenia „efektów swojskości”"1 wszędzie, gdzie się znajduje, warto zapamiętać, bo przy rozpatrywaniu ironii podmiotu natkniemy się na działanie dość podobne, co pozwoli doprecyzować konkluzję.

Mająca swe źródło w naiwności Piotra ironia uderza zatem w liczne elementy świata przedstawionego. Obdarzenie bohatera cechami negatywnymi czy, ostrożniej mówiąc, wątpliwymi moralnie i ironiczny dystans narratorski wobec niego sprawia, że unika Wittlin nieznośnego dydaktyzmu, jakim byłoby ukazanie krystalicznie czystego i naiwnego bohatera, upadającego na skutek własnej niewinności; rzec można, że nadanie Piotrowi takich cech odwzniośla i uwiarygodnia prawdy, których jest nosicielem, a które traktują o nieludzkości świata nowoczesnego, czyniącego z człowieka bierne narzędzie. Dystans, jaki wytwarza niekiedy narrator względem bohatera, służy temu, by owego bohatera widzieć w sposób pozbawiony złudzeń i oprzeć się pokusie sakralizacji „człowieka pierwotnego" oraz budowanej na tej podstawie ideologii. Utożsamienie z bohaterem jest natomiast potrzebne, by móc przyjąć wstrząsającą trafność niektórych myśli bohatera, niechcący i nieświadomie obnażającego hańbę nowoczesnego świata i mroczne strony procesów modernizacyjnych ${ }^{22}$. Znaczy to, że narrator nie może ani w pełni zaakceptować bohatera, ani też zignorować prawd o świecie, jakie z obserwacji tego bohatera wynikają. Do utrzymania tej podwójnej perspektywy służy Wittlinowi ironia naiwna.

21 O „efektach obcości” w Soli ziemi pisze Ewa Wiegandt (Wstęp, s. LXXVI): „Efekt obcości w Soli ziemi stanowi chwyt retoryczny, który pozwala świat porządkować i zinterpretować według jednej scalającej zasady: wojna, czyli cywilizacja, nie jest chaosem, tworzy nowy ład, nieludzki kosmos”. Są to działania pochodzące z poziomu narratora. Wydaje się, że opisane wcześniej intelektualne zmagania Piotra, by w obcym świecie na powrót poczuć się jak u siebie, mają charakter wręcz odwrotny.

22 Podobną dialektykę opisuje Stanisław Barańczak, analizując działanie ironii w poezji Herberta. Por. tegoż, Uciekinier z Utopii. O poezji Zbigniewa Herberta, Wrocław 1994, s. 184-185. Zob. też: J. Błoński, Romans z tekstem, Kraków 1981, s. 59-87. 


\section{Narrator i bohater: antropologia ironiczna}

Jak wskazywałam, Wittlin uruchamia w powieści dialektykę zbieżności i rozbieżności między narratorem a bohaterem oraz różne stopnie dystansu - od uwag w rodzaju:

Może na dnie tego snu o cesarskiej czapce zachowały się resztki smutnego dzieciństwa, kiedy to stary, na śmietnik wyrzucony garnek służył za wojskowe czako. I zapewne ta dziecięca pozostałość w czterdziestoletniej duszy Piotra usprawiedliwi nam fakt, którego nie należy taić, fakt, iż Piotr Niewiadomski bardzo by się cieszył, gdyby zamiast kłaniać się po cywilnemu mógł salutować (s. 35)

- po zdania takie jak:

Naczelnik - ludzki był człowiek: po mordzie - ma się rozumieć - bił, ale ze służby nie wydalał. Gdy pan naczelnik dał w mordę, trzeba go było zaraz pocałować w rękę, stuknąć się w pierś i powiedzieć - Bih me! Słowo czestne daju, to ostatnij raz! - ale kradzionego oddawać się nie musiało. To było życie! (s. 30).

Nawet jednak tam, gdzie dystans jest bardzo wyraźny, tonuje go wyznawane przez narratora przeświadczenie o tragicznej sytuacji Piotra Niewiadomskiego, skazanego $\mathrm{w}$ procesach modernizacji, kumulujących się w wojnie, na zagładę. Narratorski dystans nie służy zatem oskarżeniu, a wręcz wydaje się, że niekiedy wzmaga współczucie, w czym wyraża się szczególna rola stosowanej przez Wittlina ironii. Figura ta, będąc znakiem pewnego sposobu myślenia o świecie i ludziach, umożliwia Wittlinowi zajęcie pozycji, o której w następujących słowach pisze badaczka ironii jako instrumentu profilującego ludzkie samopoznanie:

Antropologia ironiczna [...] niesie w sobie ogromny potencjał solidarności naturalnej: śmieszność, jaka cechuje naszą krzątaninę we wszechświecie, skłania do melancholijnie pogodnego poczucia wspólnoty, które przenika bariery stworzone przez wszelkiego rodzaju tragizmy, patosy i rozczarowane aspiracje. Budzi współczucie zrodzone przez wspólność „zwykłego ludzkiego nieszczęścia”, to pozbawione pretensji zwyczajne codzienne zło, które nie szuka żadnego dramatycznego wzmocnienia, żadnych szczególnych środków wyrazu, by się wyróżnić. Antropologia ironiczna tworzy obraz powszechnego zrównania człowieka wobec losu. Jej żywiołem nie jest różnica, lecz odróżnicowanie. Z antropologii ironicznej wynika zatem, że solidarność między ludźmi zakorzenia się spontanicznie wszędzie tam, gdzie ujawnia się wspólnota losu: gdzie dochodzą do głosu powszechniki ludzkiej kondycji ${ }^{23}$.

Człowiek przedstawiony przez Wittlina jest śmieszny, niedostosowany, nierozumiejący świata mimo usilnych prób w tym kierunku, właśnie

23 A. Bielik-Robson, Inna nowoczesność. Pytania o wspótczesna formute duchowości, Kraków 2000, s. 193-194. 
po to, by tragizm jego losu wzbudził współczucie ufundowane na przeświadczeniu, że w gruncie rzeczy los każdego człowieka w nowoczesności przebiega podobnie, wśród mechanizmów daremnego (lub totalitarnego) wyjaśniania świata, który utracił podstawę. Ironię prostaczka stosuje więc Wittlin nie tylko po to, by obnażyć i zdemaskować faktyczny stan świata (w taki sposób, jak o wojnie pisali twórcy literatury pacyfistycznej, a o nowoczesności - niektórzy krytycy modernizacji), lecz również po to, by stworzyć podstawę dla autentycznego poczucia wspólnoty wszystkich ludzi, opartej nie na łączności interesów czy statusu, lecz losu.

Utożsamienie się narratora z Piotrem sprawia, że wypowiedzi Piotra o machinie wojennej zyskują „akceptację” narratora, a także, że to wszystko, co dzieje się z Piotrem - cała jego stopniowa przemiana w "nowego człowieka” - dotyczy i jego, i szeroko nakreślonego, wspólnotowego „my”. Do roli głosiciela prawdy o upadku cywilizacji predestynuje Piotra nie tyle więc jego „niewinność” i dostrzegany przez niektórych badaczy rys „Bożego prostaczka” (cecha, której wyrazistość w świetle wszystkiego, co wiemy o bohaterze, jest mocno wątpliwa), co raczej niezaprzeczalny element podobieństwa jego losu do losu narratora i wszystkich czytelników, mimo wszelkich różnic, jakie dzielą niepiśmiennego Hucuła od odbiorców nowoczesnej powieści.

\section{Ironia nadawcy: analogie i paradoksy}

W swoich wypowiedziach dotyczących świata przedstawionego powieści narrator często rozwija to, czego dowiadujemy się $\mathrm{z}$ wygłaszanej w świętej naiwności opinii Piotra. Drastyczna nieprzystawalność porządków, które wyobraźnia Piotra usiłuje z trudem uzgodnić, w wypowiedzi narratora obraca się w chwyt wskazujący na absurdalność świata nowoczesnego. Przykładem służyć może scena przysięgi rekrutów, która ma miejsce w szkolnej sali gimnastycznej:

Tutaj, gdzie na żółtych drabinkach, drążkach i trapezach wyrabiano dzieciom siłę, miały dostęp jedynie te ciała, których zdrowie stwierdziła komisja. Lecz nie w celu wypróbowania sił i zwinności sprowadzono tych ludzi do sali gimnastycznej. Tu chodziło wyłącznie o dusze. (s. 85)

Po takim przygotowaniu czytelnika narrator zauważa, zbliżając się do tonów sarkastycznych:

Albowiem cesarz Franciszek Józef uznawał w człowieku nie tylko cielesną powłokę. Nie był wyznawcą doktryny materialistycznej ani zwolennikiem teorii Haeckla. Hołdował dualizmowi i najnędzniejszemu ze swych poddanych, najciemniejszemu Hucułowi nawet nie odmawiał posiadania duszy. Zależało mu 
wszelako na porządku. Osobno brał ciała, a osobno dusze. To są dwie różne rzeczy i nie wolno ich mieszać. (s. 85)

Narrator wskazuje ironicznie, że cesarz, każąc przysięgać w imię Boże, łamie zarazem boskie prawo, wysyłając na front i czyniąc z ludzi maszyny do zabijania. Daje się tu słyszeć, pochodząca z całą pewnością od autora, ironia wymierzona we wszelki system władzy ziemskiej, szczególnie zaś - dysponującej nowoczesnymi środkami przymusu. Warto wszakże pamiętać, że drwiąc z jej dwulicowości, Wittlin jednak traktuje serio jej realne możliwości.

Narrator w powieści Wittlina jest tyleż skłonny do ironicznych komentarzy, co po prostu przedstawia sytuacje ironiczne, które - jak pisał współczesny Wittlinowi Hoffmannsthal - ujawniły się ze szczególną wyrazistością w latach pierwszej wojny światowej, rujnującej dotychczasowy porządek społeczny ${ }^{24}$. Rzeczą narratora jest zatem zarówno budowanie dystansu (do świata i do protagonisty), jak i zdawanie sprawy z „ironicznego stanu rzeczy", jaki cechuje rzeczywistość przedstawioną.

Narrator wyczulony jest szczególnie na paradoksy i przeciwieństwa w świecie przedstawionym powieści, które współtworzą sytuacje ironicz$\mathrm{ne}^{25}$ (takie jak: fakt, że zupa, którą je Niewiadomski w drodze na wojnę, kojarzy mu się z przywracającą zdrowie zupą gotowaną przez matkę; wymowne sąsiedztwo koszar i rzeźni miejskiej; sytuacja, kiedy to stojący na wadze Piotr, któremu lekarz wypisuje za pomocą ołówka cyfry na klatce piersiowej, czuje się podobny do znaczonego przez weterynarza, ubitego cielęcia). Niekiedy sam narrator przyczynia się do takiego oglądu rzeczywistości, wychwytującego dialektykę podobieństw i różnic między rzeczami i zjawiskami. W jego komentarzach znaleźć można dziesiątki porównań, zderzających ze sobą żywioł tragiczny i komiczny, realistyczny i groteskowy, to, co wysokie i to, co niskie, duchowe i materialne (feldfebel sztabowy Bachmatiuk porównany zostaje więc do Boga Stworzyciela, a gdzie indziej do mniszki, Piotr Niewiadomski - do Mojżesza itp.).

Tego rodzaju pęknięte paralelizmy często współtworzą zajmujące nas zjawisko ironii i stanowią bardzo rozbudowany obszar poszukiwań for-

${ }^{24}$ Zob. H. von Hofmannsthal, Ironia rzeczy, [w:] tegoż, Księga przyjaciót $i$ szkice wybrane, wybór i przekład P. Hertz, Kraków 1997, s. 181-184. Hofmannsthal pisze, że jego pokolenie, doświadczone wstrząsem i przełomem pierwszej wojny światowej, doskonale zdolne było zrozumieć romantyków, uciekających się do ironii po zdarzeniach rewolucji francuskiej i wojnach napoleońskich. Wittlin również uważa, że ironia jest stale obecna w ludzkim świecie, ale w poszukiwaniu wzorca nie sięga do romantyków, lecz, jak zobaczymy, do Sokratesa, a widzieć w tym wypada bardzo znaczący gest ideowy.

${ }_{25}$ Por. D.S. Kaufer, dz. cyt., s. 155-156). Na temat przeciwstawienia jako źródła efektu ironicznego w powieści Wittlina pisze Z. Yurieff, dz. cyt., s. 93. 
malnych Wittlina. Mają one wyraźną funkcję mityzacyjną (czy, równie często - antymityzacyjną): paralelizm, rujnując chronologię i przyczynowość $\mathrm{w}$ świecie przedstawionym, nadaje wprawdzie przestrzeni powieściowej funkcje symboliczne ${ }^{26}$, z drugiej jednak strony, jego często „pęknięty” charakter sprawia, że niejednokrotnie stanowi podstawę „efektów obcości” 27. Pęknięte paralelizmy, w jakich celuje Wittlin, świadczą o tym, że świat w którym nagle znalazł się Piotr, nie poddaje się opisowi znane$\mathrm{mu} \mathrm{z}$ wcześniejszego etapu życia i nie mieści się $\mathrm{w}$ tradycyjnym języku opisującym świat przednowoczesny. Więcej nawet: czas powieściowy cechuje się wszak tym, że nie można w nim już zakładać niezmiennej świadomości ludzkiej28, przeciwnie - jakiekolwiek symbole, w świecie przednowoczesnym uważane za trwałe i porządkujące rzeczywistość, w świecie przedstawionym w Soli ziemi tracą aktualność.

Jak pamiętamy, mediując między światem znanym a nieznanym, Piotr Niewiadomski usiłował dostrzec w rzeczywistości, w której się znalazł, szereg odpowiedniości, odczytywanych przezeń jako znak ładu i porządku. Bohater próbował opisać i objaśnić w ten sposób rzeczywistość, a jego opinie są jawnie nietrafne (co wszelako uderza ironicznie tyleż w Piotra, co - nawet bardziej - w struktury, które zniszczyły jego dawny świat). Warto zauważyć, że podobnych zabiegów próbuje także i narrator, czego szczególnie wymownym znakiem są jego komentarze do oglądanych scen, w których usiłuje opisać to, co relacjonuje, za pomocą biblijnych cytatów. Rozważmy następujący przykład:

Aliści nie tylko Żydom obcinano włosy. Chrześcijanom też. I leciały z głów, z bród, z twarzy - na barki, na plecy, na podłogę, w kurz, mieszały się ze sobą ciemne i jasne, gładkie i kędzierzawe, katolickie i żydowskie, lubo napisano, wyraźnie napisano, że bez woli Boga nikomu włos z głowy nie spadnie. (s. 233)

Udosłownienie biblijnego cytatu, który obok ewokowanych kontekstem znaczeń literalnych niesie tutaj także swój pierwotny sens („bez woli Boga nie stanie się nikomu żadna szkoda”), staje się źródłem pytania o boską wolę i możliwość interweniowania w ludzką rzeczywistość. Jak wynika z przewrotnego zestawienia planu wydarzeń powieści i biblijnego cytatu, Bóg najwyraźniej chciał poboru rekrutów; narrator naprowadza tym samym czytelnika na ważne szczególnie od czasów przełomu nowoczesnego ${ }^{29}$ pytanie o teodyceę. Przywołując ewangeliczną formułę, narra-

${ }_{26}$ Por. K. Jakowska, Międzywojenna powieść perswazyjna..., s. 109.

${ }^{27}$ Por. B. Bakuła, dz. cyt., s. 168.

${ }^{28}$ Por. R. Scholes, Powieść jako paradygmat etyczny?, przeł. P. Czapliński, „Pamiętnik Literacki" 1992, z. 4, s. 189.

${ }^{29}$ Por. O. Marquard, Rozstanie z filozofia pierwszych zasad. Studia filozoficzne, przeł. K. Krzemieniowa, Warszawa 1994, s. 52. 
tor stawia kwestię, dlaczego Bóg nie interweniuje w zło, które już się wydarza, i nie zapobiega złu, które za chwilę ma się wydarzyć. Można fragment ten potraktować jako wyjątkowo ironiczne wskazanie na fakt, że Bóg wszechmocny i dobry zarazem z pewnością nie istnieje (a więc prawdę, którą nowoczesna filozofia wyartykułowała $\mathrm{z}$ niezwykłą siłą) lub też ironiczne potraktowanie tego, kto frazy z Pisma Świętego rozumieć pragnie dosłownie ${ }^{30}$; można jednak również, ponad ironią (czy też - właśnie dzięki niej), dostrzec w tych słowach trafny opis sytuacji nowoczesnego człowieka, który szuka znaków obecności Boga w świecie i ze smutkiem stwierdza, że nie jest w stanie ich odnaleźć. We wszystkich interpretacjach jednak fragment ten prowadzi do wniosków o bezpowrotnym odczarowaniu nowoczesnego świata, w którym próżno wypatrywać znaków boskiej obecności, a przywoływanie Boga z pomocą świętej księgi (jak czyni to narrator) czy rytuału (jak czynią to postaci) okazuje się znakiem pustym i nieskutecznym. W tym świecie nie jest już możliwe przywoływanie boskich słów w charakterze autorytetu i trafnego opisania stanu rzeczy. Cytaty z Biblii, będące $\mathrm{w}$ planie wyrażania elementem ogólniejszej strategii stylizacyjnej przyjętej przez Wittlina, objawiają swą porażającą nietrafność wobec nowego kontekstu, w jakim zostały umieszczone; jeśli zaś czytelnik może niekiedy uznać ich trafność, to wskazuje to zarazem na głęboką ironię losu, gdyż na kartach powieści Wittlina słowa, które w Piśmie Świętym dotyczyły Boga, okazują się ujmować istotę zła $\mathrm{w}$ nowoczesnym świecie oraz wszechmocnych mechanizmów uprzedmiotowienia (jak ma to miejsce choćby w słynnej scenie przeglądu wojska przez Bachmatiuka, który we fragmencie stylizowanym na biblijny opis stworzenia świata urasta do rangi demonicznego stwórcy nowego człowieka).

\section{Ironia jako postawa moralna}

Narrator Soli ziemi to zatem ironista, który mierzy także we „własne" mity, czyli opowieści mityczne ważne dla kultury, z której wyrasta, takie jak historia biblijna czy cenny zwłaszcza dla nowoczesności mit prostaczka. Dokumentując rozpad wartości i idei, wskazuje jednak, że istnieje inna droga ku przemianie świata niż wątpliwej skuteczności droga gotowych recept ideologicznych. Ironista, którego prawdziwa opinia ujawniona zostaje dopiero wówczas, gdy jego słowa zostaną usłyszane i zinterpretowane, chce bowiem, by odbiorca podejmował twórczy namysł nad nurtującymi go zagadnieniami moralnymi i w takim, pobudzającym

${ }^{30}$ Por. D. Sperber, D. Wilson, dz. cyt., s. 103-104. 
działaniu upatruje faktycznego, głębokiego - i, koniec końców, moralnego sensu swej działalności. W świecie powieściowym (ale i w świecie nowoczesnym, w którym partycypują autor i wirtualni odbiorcy powieści), w którym nie istnieją już skuteczne rytuały ${ }^{31}$ chroniące wspólnotę przed rozpadem, a jednostkę przed zatratą sensu, w ich miejscu pojawia się właśnie ironia ${ }^{32}$, na nowo tworząca zbiorowość, nie tylko, jak była o tym mowa wcześniej, na linii narrator-bohater, lecz również na linii nadawca-czytelnik (zwłaszcza zaś ten szczególny, projektowany przez Wittlina „późny wnuk”33). Wspólnota ta zbudowana jest na świadomości marności ludzkiej kondycji, ale znosi ją z ironią właśnie i zamiast rezygnacji czy rozpaczy proponuje - empatię.

Søren Kierkegaard, stawiając pytanie „W jakim sensie Sokrates jest założycielem moralności?", powtarza za Heglem, że

Sokrates moralizowat, „ale nie w sposób stosowany w kazaniach, upomnieniach, nauczaniu ex cathedra, oschłym moralizowaniu" [...]. W rozmowach z młodzikami i starcami, szewcami i kowalami, sofistami i politykami, z obywatelami wszelkiego stanu, wnikał w zainteresowania każdego z nich i niezależnie od tego, czy chodziło o zajęcia domowe [...], czy o zagadnienia naukowe, sterował ich myśleniem od konkretnego przypadku ku temu, co ogólne, ku samej w sobie i dla siebie obowiązującej prawdzie i pięknu ${ }^{34}$.

Sokrates staje się w tym ujęciu mistrzem moralności, nie dlatego jednak, by głosił konkretne zasady moralne, lecz dlatego, że skłaniał nieustannie do namysłu nad tym, co moralne - resztę zaś drogi odpowiednio nastrojony uczeń przebyć potrafił wszak samodzielnie. Jak zaś pamiętamy, jednym z dwóch narzędzi sokratejskiego nauczania, obok majeutyki, była właśnie - ironia. Zdaniem Kierkegaarda, w przeciwieństwie do prowadzącej do utraty wszelkiego znaczenia ironii romantycznej, „zdrowa” ironia sokratyczna stawia człowiekowi przed oczy horyzont sensu i wiary $\mathrm{w}$ pojęcia, zarazem kwestionując przyjmowanie z góry postawy niezachwianej pewności ${ }^{35}$. Nic więc dziwnego, że piętnasta teza dołączona do

31 D. Siwor, Dokad zmierza Piotr Niewiadomski - o bohaterze „Soli ziemi” $w$ kontekście mityczno-rytualnym, [w:] Etapy Józefa Wittlina..., s. 67.

32 Por. A. Bielik-Robson, dz. cyt., s. 211-212. Wedle autorki, ironia to „trop, który $\mathrm{w}$ zastępstwie intensywnych rytualnych doznań [...], daje [...] niemal to samo. Tylko ironia bowiem potrafi wyrazić stan, w którym znikają różnice, $\mathrm{z}$ w zamian nie pojawia się żadna tożsamość; tylko ironia potrafi oprzeć się potrzebie definicji”.

${ }^{33}$ Por. J. Wittlin, Mały komentarz do „Soli ziemi”, [w:] tegoż, Sól ziemi..., s. 292.

${ }^{34} \mathrm{~S}$. Kierkegaard, O pojęciu ironii z nieustajacym odniesieniem do Sokratesa, przeł. i posłowiem opatrzyła A. Djakowska, Warszawa 1999, s. 223. Kierkegaard cytuje tu Heglowskie Wyktady z historii filozofii.

35 Tamże, s. 210-211. Por. też: A. Bielik-Robson, dz. cyt., s. 214-215. „[ironia] nie pozwala nam popaść w 'błąd uniwersalistyczny', który pomimo wszystkich dobrych intencji, 
Kierkegaardowskiej rozprawy o ironii brzmi: „Tak jak filozofia zaczyna się od wątpienia, tak godne tego miana życie człowieka zaczyna się od ironii" 36 .

Wittlin nie przypadkiem podejmuje właśnie trop ironii sokratejskiej, nie zaś romantycznej. Ta druga, zrodzona na gruncie nowoczesnym, zbytnio ryzykuje (co wypominał jej Hegel) ześlizgniecie się w czystą negację i głoszenie nicości ${ }^{37}$. By otoczonemu przez nowoczesny chaos moralny człowiekowi dopomóc, Wittlin sięga więc do narzędzia stworzonego wówczas, gdy światem nie zachwiała jeszcze pokusa niepowstrzymanego rozwoju, niweczącego to, co absolutne i etyczne. Zdając sobie sprawę, że jednoznaczne formuły moralne służyć mogą tak dobru, jak i opresyjnej działalności (gdyż taka jest natura formującego zasady moralne człowieka), za pomocą ironii uchyla jednoznaczność pojawiających się na kartach powieści i funkcjonujących na zasadzie cytatu kategorycznych stwierdzeń; jednocześnie jego ironia, w odróżnieniu od ironii romantycznej, nie jest gestem retorycznym wymierzonym przeciwko światu, lecz przeciwnie, chce podtrzymywać zasadność wiary - nie tyle wiary w świat, co wiary w siłę ludzkich gestów obliczonych na uczynienie świata moralniejszym.

Kierkegaard kilkakrotnie wskazuje w swej książce, że działalność Sokratesa stanowiła koniec dawnego porządku i początek nowego ${ }^{38}$. Warto zauważyć, że narrator powieści Wittlina właśnie za sprawą ironii zajmuje równie pograniczną pozycję: podzwonne, jakie, ironicznie mierząc w Piotra Niewiadomskiego, odprawia nad światem przednowoczesnym, to nie tylko znak nieubłaganego nadejścia nowego porządku (jak ma to miejsce $\mathrm{w}$ świecie przedstawionym). Ironia, jaka Wittlin uderza w nowoczesny świat, stanowi o ciągłości, jaka pomimo oczywistych różnic i zaznaczanego dystansu istnieje między narratorem a Niewiadomskim. Ironiczna pozycja narratora jest $\mathrm{w}$ tym sensie także początkiem etycznego przewrotu. Jego zalążkiem jest nie tylko etyczna przewaga, jaką koniec końców osiąga niepiśmienny i daleki od doskonałości moralnej Hucuł nad nowoczesną rzeczywistością (poprzestanie na tym miałoby w gruncie

zawsze prędzej czy później owocuje projekcyjną - a tym samym opresyjną wobec innych wizją wspólnej wszystkim natury ludzkiej. Nie pozwala też zanurzyć się nam bez reszty [...] w hermetycznej, plemiennej obojętności wobec innych [...]” (s. 217).

36 S. Kierkegaard, dz. cyt., s. 10.

37 Traktowanie przez filozofię ironii romantycznej nie wyczerpuje, rzecz jasna, wszystkich aspektów tego złożonego zjawiska, bywa raczej (jak chyba dzieje się w przypadku Hegla) uproszczeniem na potrzeby dobitnie brzmiącej tezy. Sprawy tej jednak, jako zbyt obszernej, w tym miejscu omówić nie mogę.

38 Tamże, s. 206, 212. 
rzeczy charakter zniechęcającego do dalszych działań resentymentu), lecz także gest ironisty, który zamiast idei proponuje nieufność i w ukryty sposób zaraża tęsknotą za idealnością. Zaznaczona w postaci głównego bohatera łączność z formacją wcześniejszą - przednowoczesną - pełni w przypadku Wittlina funkcję podobną, jak dla Sokratesa jego klasycznośćc ${ }^{39}$, mianowicie pozwala mu udźwignąć ironię, nie pozwalając jej ześlizgnąć się w negatywność.

Postawę dystansu do świata i jednoczesnego „dawania światu szansy" osiągnął Sokrates na drodze rozmów z konkretnymi ludźmi, których napotykał na swej drodze i których zarażał swoim nastawieniem do rzeczywistości. Wittlinowska strategia pisarska przyjęta w Soli ziemi jest $\mathrm{w}$ gruncie rzeczy podobna, gdyż, podobnie jak tamta, zasadza się na ironii. Korzystający z jej dobrodziejstw nadawca każdorazowo zmusza odbiorcę do uświadomienia sobie ramy interpretacyjnej, układu odniesienia, w ramach którego ironia działa. To „przyjęcie perspektywy” implikuje szereg działań oraz postaw, nakazuje odbiorcy czujność i podjęcie wysiłku refleksji, kojarzenia i rozdzielania ${ }^{40}$. Im bardziej złożona jest ironia, tym skuteczniej aktywizuje odbiorcę, nakazując mu nieustanną czujność i postawę ciągłego zapytywania siebie samego o ocenę opisywanej sytuacji czy zjawiska. Wydaje się, że wszechobecność ironii w powieści Wittlina traktować należy także $\mathrm{w}$ tych kategoriach: figura ta, będąc jednocześnie postawą podmiotu, konstytuuje literaturę moralną, pragnącą człowieka kształtować, choć nie pouczać, nieustannie przypominającą o wielości punktów widzenia, z jakich można obserwować rzeczywistość, ale nie pozwalającą przystać naiwnie na pogląd, że wszystkie z nich są $\mathrm{z}$ moralnego punktu widzenia tyle samo warte.

\section{LITERATURA}

Barańczak S., Uciekinier z Utopii. O poezji Zbigniewa Herberta, Wrocław 1994.

Bakuła B., „Sól ziemi” Wittlina w naukowym opracowaniu, „Teksty Drugie” 1994, nr 5/6, s. 167-169.

Błoński J., Romans z tekstem, Kraków 1981.

Biała A., Wittlinowski mit o wiecznym pokoju, [w:] tejże, W kręgu polskich mitów literackich XX wieku, Piotrków Trybunalski 2000, s. 26-60.

Bielik-Robson A., Inna nowoczesność. Pytania o wspótczesna formułe duchowości, Kraków 2000.

Bolecki W., Poetycki model prozy międzywojennej, Wrocław 1983.

${ }^{39}$ Zob. S. Kierkegaard, dz. cyt., s. 206.

40 Por. D.S. Kaufer, dz. cyt., s. 157. 
Cudak R., „Otom przed Toba, Abraham”. Lektura wiersze Józefa Wittlina „Trwoga przed śmiercia”, [w:] Szkice o poezji Józefa Wittlina, red. I. Opacki, Katowice 1990, s. 34-54.

Hofmannsthal H. von, Ironia rzeczy, [w:] tegoż, Księga przyjaciót i szkice wybrane, wybór i przekład P. Hertz, Kraków 1997, s. 181-184.

Jakowska K., Międzywojenna powieść perswazyjna, Warszawa 1992.

Jakowska K., Z dziejów ekspresjonizmu w Polsce. Wokót „Soli ziemi”, Wrocław 1977.

Juszkiewicz P., Cień modernizmu, Poznań 2013.

Kaufer D.S., Ironia, forma interpretacyjna $i$ teoria znaczenia, przeł. M.B. Fedewicz, [w:] Ironia, red. M. Głowiński, Gdańsk 2002, s. 145-163.

Kerbrat-Orecchioni C., Ironia jako trop, przeł. M. Dramińska-Joczowa, [w:] Ironia, red. M. Głowiński, Gdańsk 2002, s. 109-143.

Kierkegaard S., O pojęciu ironii z nieustajacym odniesieniem do Sokratesa, przeł. i posłowiem opatrzyła A. Djakowska, Warszawa 1999.

Kierkegaard's International Reception, vol. 2, ed. J. Stewart, Burlington 2009.

Kłosiński K., Cztery interpretacje ofiary Abrahama. Wokót wiersza Józefa Wittlina „Trwoga przed śmiercia”, [w:] Szkice o poezji Józefa Wittlina, red. I. Opacki, Katowice 1990, s. 55-72.

Korolko M., Sztuka retoryki, Warszawa 1990.

Marquard O., Rozstanie z filozofia pierwszych zasad. Studia filozoficzne, przeł. K. Krzemieniowa, Warszawa 1994.

Maciejewska I., Józef Wittlin, [w:] Poeci dwudziestolecia międzywojennego, t. 2, red. I. Maciejewska, Warszawa 1982, s. 489-519.

Muecke D.S., Ironia: podstawowe klasyfikacje, przeł. G. Cendrowska, [w:] Ironia, red. M. Głowiński, Gdańsk 2002, 43-74.

Rogoziński J., Wstęp, [w:] J. Wittlin, Poezje, Warszawa 1981, s. 5-17.

Scholes R., Powieść jako paradygmat etyczny?, przeł. P. Czapliński, „Pamiętnik Literacki" 1992 , z. 4, s. 186-194.

Siwor D., Dokąd zmierza Piotr Niewiadomski - o bohaterze „Soli ziemi” w kontekście mityczno-rytualnym, [w:] Etapy Józefa Wittlina, red. W. Ligęza, W.S. Wocław, Kraków 2014, s. 59-72.

Sperber D., Wilson D., Ironia a rozróżnienie między użyciem a przywołaniem, przeł. M.B. Fedewicz, [w:] Ironia, red. M. Głowiński, Gdańsk 2002, s. 75-108.

Tischner Ł., „Sól ziemi”, czyli tęsknota do eposu, [w:] Etapy Józefa Wittlina, red. W. Ligęza, W.S. Wocław, Kraków 2014, s. 13-40.

Wiegandt E., Wstęp, [w:] J. Wittlin, Sól ziemi, Wrocław 1999.

Wittlin J., Hymny, Poznań 1920.

Wittlin J., Orfeusz w piekle XX wieku, Kraków 2000.

Wittlin J., Pisma pośmiertne $i$ inne eseje, Warszawa 1991.

Wittlin J., Sól ziemi, Wrocław 1991.

Wocław W.S., Świat - igrzysko ironisty. Rozważania o „Soli ziemi” Józefa Wittlina, [w:] Etapy Józefa Wittlina, red. W. Ligęza, W.S. Wrocław, Kraków 2014, s. 89-97. Yurieff Z., Józef Wittlin, przeł. M. Szczubiałka, Izabelin 1997.

Ziomek J., Retoryka opisowa, Wrocław 2000. 
